Island Studies Journal, Vol. 9, No. 1, 2014, pp. 69-78

\title{
Alderney: gambling, Bitcoin and the art of unorthodoxy
}

\author{
John Connell \\ University of Sydney \\ Australia \\ john.connell@sydney.edu.au
}

\begin{abstract}
Small islands are disadvantaged by conventional development strategies and have sought unusual means of achieving economic development and raising their global profiles. The small Channel Island of Alderney, with a largely non-existent physical resource base, and steady population decline, has sought to develop several service sector activities, increasingly involving the internet and virtual activities. Internet gambling has proved successful. Bitcoin minting offers unique possibilities. Alderney has achieved economic development without significant local assets other than creativity and ingenuity, and a somewhat distinctive political status.
\end{abstract}

Keywords: Alderney; Bitcoin; Channel Islands; coins; gambling; services; unorthodoxy

(C) 2014 - Institute of Island Studies, University of Prince Edward Island, Canada.

\section{Introduction}

Small island states have long sought to develop conventional export-based economies but are disadvantaged by size, location and a range of other factors. The wide-ranging challenges faced by small island states, especially in succeeding in the world economy, have been widely documented, and include environmental, economic and social factors. Generating modern economic activity let alone economic growth has proved difficult for a range of reasons stemming from limited human and physical resources, inadequate infrastructure, high energy costs and high wages, and the lack of economies of scale. Set against the range of disadvantages, the comparative advantages of smallness and isolation are few. Conventional development proposals have thus encouraged small islands to develop niches where they have some form of comparative advantage (Connell, 2013). However islands have inevitably faced competition from larger countries, with economies of scale and intervening opportunities for market access, hence only the most exceptional products, such as ylang-ylang in the Comoros, have uncontested markets. In the Channel Islands, Guernsey and Jersey respectively once had thriving tomato and potato industries but these have largely disappeared. Tourism has been successful in many small islands, otherwise lack of success in achieving development through conventional means - local agricultural or manufacturing production (niche or otherwise) and thus trade - has contributed to the emergence of a wide range of unusual and unorthodox strategies for achieving access to incomes, economic growth and development, primarily in a range of service activities. This paper seeks to examine a new variant and niche in the service sector from the small Channel Island of Alderney. 
From the late 1960s, when international capital became more mobile and rapid global telecommunications were established, many small states became offshore financial centres of various kinds: 'attempting to become a tax haven was a sensible livelihood strategy for many micro-territories faced with the end of colonial rule and the lack of other obvious sources of income or export earnings' (Moore, 2011, p. 1770). The Channel Islands, embracing the two Crown Dependencies of the United Kingdom, Jersey and Guernsey (the latter including the islands of Sark and Alderney, each with their own parliaments), though not facing decolonisation, experienced similar economic circumstances, and its tax haven activities expanded. Tax havens experienced boom years from the 1970s when the electronic mobility of capital became particularly rapid, deregulated markets and privatisation were the norm, international trade and investment were expanding and rapid increases in global oil prices created a surge in the volume of Eurodollars that required deposit.

However, this century has brought a global assault on tax havens, from various states (including the United Kingdom), the EU and civil society, through pressures to reduce tax evasion and associated illegal activities, and to challenge legal but complex tax avoidance schemes which are seen to go beyond what is ethically acceptable, particularly since the financial crisis of 2008. Consequently the activities of several offshore finance centres were significantly curtailed by external intervention (Sharman, 2011). Corruption risks from poorly monitored offshore banking activities, rampant in the 1990s, substantially declined following global concern with terrorism and money laundering, but local economic benefits were greatly reduced, prompting countries with tax havens to seek to diversify into other areas.

At the same time, various small island states developed even more unusual strategies for generating revenue. Some, like Tuvalu and Marshall Islands, established shipping registries providing flags of convenience for ships that never enter their waters. Several states have sold diplomatic passports, mainly to Chinese entrepreneurs (Van Fossen, 2007). Hosting 'reality' television shows has brought in occasional wealth (and tourist publicity). Fiji earned about \$20 million from staging Celebrity Love Island in 2005, and the Cook Islands, Vanuatu and Samoa have all hosted versions of Survivor and other series. For many years the sale of stamps, later 'telephone-sex' and the renting of its top-level internet domain (.tv) proved valuable economic strategies for Tuvalu (Boland \& Dollery, 2006). Throughout this century, .tv has generated US\$4 million a year for Tuvalu. Making land available for second homes, military exercises and occupation, and refugee detention may provide substantial rental incomes

Stamps and coins have long been important to many small island jurisdictions. Some of the smallest dependent territories, like Pitcairn and Wallis and Futuna, have had significant overseas markets (often for stamps whose designs had nothing to do with those territories, and which never actually emanated from there) while multi-island states such as the Cook Islands and Tonga brought out stamps for particular islands. Pitcairn, which markets both stamps and its domain name, has been described as a 'postage stamp republic' (Steinberg \& McDowell, 2003). At least in the 1980s, stamps were valuable and successful forms of economic activity (Bertram, 1986); but maintaining that has proved impossible, because of the propensity of several states to bring out too many stamps of limited aesthetic value or local relevance and the global decline of philately. 
Local coins have also been minted for many small states; Niue licensed the minting (in New Zealand) of SpongeBobSquarePants coins for Nickelodeon and Star Wars coins for Lucas Films in 2011 (RNZI, 2011; Examiner.com, 2010). However, such gimmicks usually earned little and were quite unsustainable. Stamp, coin and passport sales, being a tax haven or providing flags of convenience are disproportionately more attractive to the smallest states (Slemrod, 2008), simply because even the little revenue that they generate has some value. Passport sales, as in Vanuatu, and casinos in the Marianas (Tinian), have posed serious regulatory and management problems, while other activities can be hard to monitor and engender some social costs. Economic benefits may be small.

In such varied ways, rental incomes are particularly significant in smaller dependent territories, where autonomous sources of income are few. Yet even service incomes are not easily won, and fluctuations in morality (that ended Tuvalu's 'phone-sex' income), global tastes (the virtual demise of philately) and especially strategic interests alter their significance. That they remain of considerable significance is indicative of the limited status of conventional development strategies. That is particularly true for the very small island of Alderney where a number of distinctive strategies have been introduced.

\section{Alderney}

Alderney is the third largest island in the Channel Islands, some $16 \mathrm{~km}$ off the coast of France, and is part of the Bailiwick of Guernsey. Somewhat isolated from the larger Channel Islands, and with its own States government, it has a land area of just $8 \mathrm{~km}^{2}$ and a population of 1,903 in 2013. A trivial, residual agricultural and fisheries economy has given way to tourism and a number of other service activities. Alderney is a self-governing democracy, with a Parliament (the States of Alderney) of ten members, but is heavily reliant on Guernsey for public service provision, such as policing, health and education. Defence and foreign policy are covered by the United Kingdom; however the island is outside the European Union and is an offshore finance centre (much like Jersey, Guernsey and the Isle of Man, but on a much smaller scale). See Figure 1.

Figure 1: Map of the Channel Islands, showing the location of Alderney. Source: http://www.worldlicenseplates.com/maps/AT_CHNL.gif

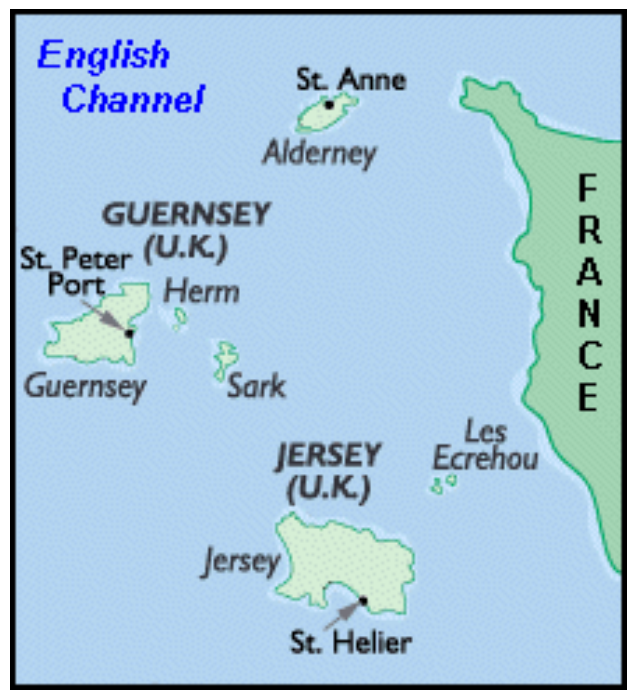

In this century, the island population had declined rapidly. The population was 2,294 in 2001 hence decline is substantial, and ageing is problematic (with the population over 65 increasing from 24 percent to 33 per cent between the two census dates) and has posed questions about the sustainability of the island and its economy. There has been a steady immigration of retirees and an outmigration of those in working age groups, hence problems in maintaining and developing small businesses. However tourism is slowly reviving with the island receiving about 3,000 visitors a year, but it is a high-cost tourism, and numbers are a third of what they were in the 1980s. Shops are closing faster than 


\section{J. Connell}

they are opening, and new ones tend to be run as hobbies, hence employ few people, and/or are seasonal. Thus a new bookshop, opened in 2010, 'won't exactly be crammed with customers; it is seen more as a service to the community' (quoted in Anon, 2010). Consequently there are few local employment opportunities. While the island's official webpage states 'For a growing community of ambitious entrepreneurs Alderney offers a compelling mix of state-of-the art technical resources, supportive government, low taxation and a unique family-focused lifestyle' (States of Alderney, 2014), in practice population decline is proving hard to redress.

Most immigrants are retirees who have moved because of Alderney's status as a tax haven and because constraints on immigration are less than in the other Channel Islands. Alderney residents have a 20 percent income tax rate (substantially less than in the United Kingdom) and no VAT, inheritance tax or capital gains tax. Alderney is thus both a tax haven - with about 500 registered companies - and haven for those who seek to pay low taxes: simultaneously an onshore and offshore tax haven. A substantial consequence of a low rate of income tax is the need to generate additional income to provide the range of services that a somewhat isolated small island necessarily requires. As elsewhere, greater regulation of offshore finance centres has posed problems for the Channel Islands generally, and for Alderney; hence, a diversity of development strategies have been sought that both increasingly typify some of the trends and transitions that have occurred in several small island states, and have also gone beyond them, and indicate how in very small islands unusual strategies, of little value in large states, can be of considerable benefit.

Alderney has issued its own commemorative coins since 1989, in conjunction with the United Kingdom Royal Mint. The coins, issued to commemorate important events in local history, have been popular throughout the world with coin enthusiasts and occasional collectors. The coins are sold in Alderney and through the Royal Mint. Alderney has marketed its own stamps since 1983. Alderney stamps are released annually as commemorative issues, backed up by a definitive set every decade. The stamps are produced by Guernsey's Postal Administration. Since the first issue, unlike many comparable small jurisdictions, the stamps have largely reflected island themes, including the island's military history (regiments that were garrisoned there and the forts which they manned), ships (both naval and civilian) and wildlife (mainly birds, but also beetles and marine life). Concorde's last flight and what would have been the $70^{\text {th }}$ birthday of John Lennon have also been marked by special coins (Tax Free Gold, 2013; BBC News, 2010). The focus on locality, and the relative infrequency of production, has enabled them to retain a significant market. Neither coins nor stamps however constitute expanding markets.

Development opportunities expanded with superior electronic communications, the emergence of the internet and the arrival of two internet gambling companies who moved to the island in the 1990s and established state of the art IT links. The development of IT has enabled Alderney to become one of relatively few jurisdictions with internet gambling. At the margins of legality in some jurisdictions, internet gambling provides significant revenue for a small number of countries, notably Antigua and Barbuda, which famously managed to use WTO legislation to fight off massive legal pressures from the United States to successfully retain its industry (Cooper, 2011). Other jurisdictions that have established internet gambling are few, but include Gibraltar, the Isle of Man and Alderney. Rather like Antigua each are small jurisdictions, but backed by a powerful gambling industry, which raised questions over the extent to which internet gambling was a vice or a virtue. Indeed critics have defined Alderney simply as 'a playground for online, offshore gambling' (Shaxson, 2011, p. 16). 
Internet gambling began in 1997 and was quickly attractive to gambling companies because of the island's lack of gambling and corporation taxes. At the peak of gambling on Alderney in the early 2000s, in the sense that the number of gambling industry employees on the island was greatest, almost 100 jobs were generated on the island but these gradually disappeared as gambling became exclusively online.

Alderney is reputed to transmit more internet e-gambling traffic than any other place on the globe, including Antigua, and is larger than the combined activity of its three European rivals: Isle of Man, Gibraltar and Malta. Likewise, it was reputed to have a higher degree of probity than many competing jurisdictions (Wilsenach, 2002). The IMF reported that egambling licence holders on Alderney had over 3 million customers and conducted £2.1 (US\$3.3) billion worth of transactions in 2009 (quoted in Bowers 2012). Although the regulatory body, the Alderney Gambling Control Commission (AGCC), is based in Alderney (where it supports 19 jobs), all the high powered IT infrastructure is located in Guernsey, since Alderney does not have an adequate electricity supply to power the necessary data centres. By 2011, it was estimated that the AGCC's contribution to Alderney had amounted to £12 (US\$20) million over the previous six years, which had helped repair the quay, provide a water filtration plant and rebuild the court house. The gambling industry was still steadily growing and by 2012 some 57 companies were registered by the AGCC, an increase from the 34 of 2007. In 2012, licence fees contributed $£ 4.8$ (US\$ 8) million to Alderney, enabling an overall revenue of $£ 2.8$ (US\$4.4) million, after the deduction of staff costs and other overheads (AGCC, 2013, p. 24). To facilitate establishing a global e-commerce, e-gaming or e-betting presence, the States of Alderney has passed legislation to further the development of ecommerce on the island and to support the electronic transactions of businesses.

\section{Bitcoin}

Thus far, Alderney has followed a strategy broadly similar to that of the other Channel Islands and with a range of service activities with parallels elsewhere. Most recently it has sought to go beyond these into uncharted virtual territory. Late in 2013, Alderney announced that it would seek to mint Bitcoins. Bitcoin is 'an open source peer to peer electronic money and payment network' that has no visible presence and was invented by an anonymous American (or group of people) in 2009 (under the pseudonym 'Satoshi Nakamoto'). Digital currencies, like Bitcoin, are forms of electronic money that effectively act as an alternative currency. Bitcoin has thus been described as a 'cryptocurrency' because it uses cryptography to secure transactions. It differs from virtual money in being used in transactions with real goods and services. Cryptocurrencies have been designed to gradually introduce new units of currency, but placing a cap on the total amount of currency in circulation, to copy the scarcity (and value) of precious metals and to avoid hyperinflation. Specialized computers, using complex systems, prevent people from copying and spending the same bitcoin multiple times, a particular problem for cryptocurrencies. Bitcoins are stored by associating them with cryptographically generated addresses, which themselves are stored in 'digital wallets' on web services, on local hard-drives and mobile devices, or even on paper print-outs. No central control or regulation exists, hence it is not backed by a central bank, or by gold, reducing its acceptance as a means of exchange. 
For the first two years of their existence, crypto-currencies gained gradually increasing attention from the media and public, but Bitcoin has been by far the most prominent. After 2011, interest rapidly increased. The publicity attached to Bitcoin led to its value increasing, reaching a peak for an individual 'coin' of US\$1,242 in November 2013, having climbed from as low as US\$40 in March. A month later, its value was around US\$600, after China banned the country's banks from trading in it, and hovered around US\$870 in January 2014. That rise gave Bitcoin greater positive exposure in a wider context, after a phase when some transactions were associated with illegal activities (with, in 2012, the FBI closing down one service - Silk Road - which specialized in illegal drugs), and Bitcoins have increasingly been used as payment for legitimate products and services. Businesses have an incentive to accept the currency because transaction fees are lower than bank fees and the 2 to $3 \%$ typically imposed by credit card processors. Bitcoin has proved particularly attractive to libertarians who dislike quantitative easing and all forms of governement regulation. Speculators have however also been attracted to Bitcoin, contributing to volatility and price swings, and critics have warned of speculative bubbles. Its supporters however believe that it could be widely adopted as a means of making payments outside traditional banking systems. Nonetheless, in early 2014, the use of Bitcoin in the retail and commercial marketplace was still relatively small compared with its larger use by speculators (e.g. Daily Finance, 2014). Its eventual future in trading systems therefore remains uncertain.

Centred on this novelty, and the growing interest in and publicity for Bitcoin, Alderney has sought to become a hub for controlled legal trading in Bitcoin, raising the idea of creating a physical coin to back the virtual currency, and with support from the United Kingdom Mint, its longstanding commercial partner in issuing commemorative coins. Alderney also sought to become a hub for Bitcoin businesses, offering a range of services and launching these by issuing a hard Bitcoin. Alderney was therefore seeking to be the first jurisdiction to mint physical Bitcoins, amidst a global race to take advantage of the rapidly growing virtual currency, and thus become the first international centre for Bitcoin transactions. That requires setting up a cluster of services that are compliant with anti-money laundering rules, including exchanges, payment services and a Bitcoin storage vault (Wild, 2013). It would be the world's first international centre for Bitcoin transactions. Holders of Alderney Bitcoins would not be able to use them in stores but would be able to exchange them for virtual Bitcoins by travelling to Alderney. They would not otherwise be official legal tender. The virtual Bitcoins backing the physical coins would be held in digital storage in Alderney. Alderney would receive royalties from sales of the coins which could be redeemed for sterling at any point in Alderney for the price of the Bitcoin at that time.

The special physical Bitcoin was intended to be part of the Royal Mint's commemorative collection, which includes limited edition coins and stamps that are normally bought by collectors, thus enabling its arrival to gain wider publicity and a means of legitimization. The coin would have a gold content - a figure of $£ 500$-worth (US\$830) was proposed - so that holders could conceivably melt and sell the metal if the exchange value of the currency collapsed (Wild, 2013). The physical coins, like other similar tokens, would be collectors' items rather than circulated, with a gold content that would further their appeal and allow them to retain value should Bitcoin's price crash. More importantly, they would also serve as promotional tokens for the more 'serious' Bitcoin payment and exchange services. 
However, Bitcoins, and other digital currencies, still have no legal recognition as currencies in any major jurisdiction. Although the UK government does not recognise Bitcoin as a currency, during 2013 it became more open to hearing the case for its regulation by a jurisdiction like Alderney. Like the UK, many legal authorities are still struggling to understand this crypto-currency, let alone develop appropriate legal regulation for it. No legislation has yet been tabled specifically for digital currencies, though exchanges and payment processes generally fall under anti-money laundering regulations. While Bitcoin is legal, it is a step back from making financial transactions more traceable in an age of electronic banking; hence, Alderney's proposal may not gain Royal Mint acquiescence. There is also concern in Guernsey about the potential reputational downside of this project for the financial industry of Guernsey which is dependent on a 'whiter than white image' where the Bitcoin initiative may be just a bit of 'financial quackery'. The head of Guernsey Finance, responsible for promoting the island's financial industry globally, has commented,

We are in an ever-changing world ... if the Bailiwick can play a part in addressing concerns by developing the currency, including its regulation, that could be very positive. In turn, we may enhance our image as an innovative place to do business and may even be recognized as a leading jurisdiction in the field; but any move in this direction may need to carry the label 'proceed with caution' (BBC News, 2013).

Moreover, if Alderney's proposal succeeds, this would be a major development for Bitcoin, which has struggled to be recognized by governments as a legitimate form of payment due to its early association with illegal activities.

Still, given the real problems attached to developing a physical bitcoin (notably that the value of the two things separately - gold and Bitcoin - would be higher than the value of the two together), it may be that the proposal never leads to the creation of a physical entity. Yet already it has proved a valuable means of publicity for Alderney moving towards becoming a legal jurisdiction for trading and managing bitcoins. It is an innovative and intriguing proposal that may succeed and so combine financial benefits with tourism and a new place branding.

\section{Conclusion}

Global governance and participation in the international economy have provided opportunities for small states and islands but also challenges. In the long run, and thus far, these challenges have outweighed the costs, hence small islands have sought increasingly ingenious ways of responding to conventional disadvantages in an increasingly global economy. Inability to compete successfully in the more obvious components of the modern economy, other than tourism, has resulted in less conventional strategies. Over time those strategies have increasingly involved variants on 'invisible' service economies - such as banking, insurance and internet gambling - where physical impacts on the islands are usually non-existent. In short this has meant breaking out of the physical resource trap. 
Alderney has gradually devised a range of means of intersections with the global economy that have increasingly taken virtual form. Alderney currently generates $£ 40$ (US\$65) million a year from online gambling, but must pay $£ 37$ (US\$60) million to Guernsey, on which it relies to provide public services for its 1,900 inhabitants (AGCC, 2013). The Bitcoin proposals would not only provide a path towards greater financial independence, but also diversify the economy on the island. Alderney's approach to Bitcoin emphasizes intriguing synergies between numismatics, e-commerce, tourism and offshore finance. While the United Kingdom handles the foreign relations of each of the Channel Islands, and Alderney is without fiscal independence, the details of such matters as the legal restrictions and controls over online gambling and trading in bitcoins, or other virtual internet activities, are subject to island law. Alderney's small but significant political distinctiveness - even as a dependency of a dependency - has given it unusual scope in a global system.

Governments in small island states and territories are constrained to make seemingly improbable and unorthodox economic choices, resorting to 'pseudo-development strategies' (Baldacchino, 1993) - such as internet gambling and Bitcoins - especially where overseas aid is non-existent and tourism stagnant. Such options are more likely to be taken by the smallest islands, like Alderney, rather than Guernsey, where other more 'mainstream' options exist. The IT revolution has transformed some island development strategies. Islands that have benefited from such invisible service economies are mainly those in dependent territories where some degree of security is provided by attachments to distant metropolitan nations. Virtual finance, if backed by the UK Mint, represents a secure development. For a very small island, Alderney has been able to use its separate legislature, a measure of independence, plus legal and technological expertise in the quest for a distinct identity and a distinct structure of development: an excellent example of the 'creative political economy' that exists in a number of other dependent territories (Baldacchino \& Milne, 2008). Globalization is thus both prerequisite and outcome, while global strategies both benefit from and undermine distinct political status.

However unorthodox, Bitcoins have placed Alderney - perhaps briefly - on the global map. That alone cannot be a disadvantage for a small island with a declining population. Yet it requires approval from the Royal Mint. However improbably, such apparently bizarre development options suggest that even the smallest islands, as long as they have minimal distinct political status, and an abundance of creativity and ingenuity, have the means of making some choices that enable a contemporary form of development that, beyond tourism, would otherwise be unobtainable, and which otherwise have no tangible link to local human and physical resources.

\section{References}

Alderney Gambling Control Commission (2013). 2012 Annual Report and Accounts.

Alderney. Retrieved from

http://www.gamblingcontrol.org/userfiles/file/AGCC_R\&A_2012.pdf

Anon (2010). Moving to the tax haven on Alderney. This is Money, 9 July. Retrieved from http://www.thisismoney.co.uk/money/mortgageshome/article-1698196/Moving-to-thetax-haven-of-Alderney.html

Baldacchino, G (1993). Bursting the bubble: the pseudo-development strategies of microstates. Development and Change, 24(1), pp. 29-51. 
Baldacchino, G., \& Milne, D. (2009). Success without sovereignty: exploring sub-national island jurisdictions. In G. Baldacchino \& D. Milne (Eds.) The case for non-sovereignty: Lessons from sub-national island jurisdictions (pp.1-10). Abingdon, UK: Routledge.

BBC News. (2010). John Lennon's 70 ${ }^{\text {th }}$ birthday celebrated on Alderney coin. November 2. Retrieved from http://news.bbc.co.uk/local/guernsey/hi/people_and_places/arts_and_culture/newsid_91 49000/9149904.stm

BBC News. (2013). Alderney Bitcoin currency a 'reputational risk', 4 December. Retrieved from http://www.bbc.co.uk/news/world-europe-guernsey-25206843.

Bertram, G. (1986). Sustainable development in South Pacific micro-economies. World Development, 14(7), pp. 809-822.

Boland, S., \& Dollery, B. (2006). The value and viability of sovereignty-conferred rights in MIRAB economies: the case of Tuvalu. Pacific Economic Bulletin, 21(2), pp. 140-154.

Bowers, S. (2012). Alderney, the unlikely hub for a global, online gambling industry. The Guardian, 4 July. Retrieved from http://www.theguardian.com/uk/2012/jul/04/alderney-hub-online-gambling

Connell, J. (2013). Islands at risk: Environments, economies and contemporary change. Cheltenham, UK: Edward Elgar.

Cooper, A. F. (2011). Internet gambling offshore: Caribbean struggles over casino capitalism. New York: Palgrave Macmillan.

Daily Finance. (2014). Can the Kings help Bitcoin become the coin of the retail realm? January 23. Retrieved from http://www.dailyfinance.com/2014/01/23/kings-bitcoin-retailacceptance/

Examiner. com. (2010). Small island nation minting Star Wars coins. August 12. Retrieved from http://www.examiner.com/article/small-island-nation-minting-star-wars-coins

Moore, M. (2011). Globalization and power in weak states. Third World Quarterly, 32(10), pp. 1757-1776.

RNZI. (2011). Niue/New Zealand Mint launch Sponge Bob silver. October 28. Retrieved from http://www.radionz.co.nz/international/pacific-news/200514/niue-new-zealand-mintlaunch-sponge-bob-silver

Sharman, J. (2011). The money laundry: Regulating criminal finance in the global economy. Ithaca NY: Cornell University Press.

Shaxson, N. (2011). Treasure islands: Tax havens and the men who stole the world. London, UK: Bodley Head.

Slemrod, J. (2008). Why is Elvis on Burkina Faso postage stamps? Cross-country evidence on the commercialization of state sovereignty. Journal of Empirical Legal Studies, 5(4), pp. 683-712.

States of Alderney. (2014). Living in Alderney. Retrieved from http://www.alderney.gov.gg/article/4054/Living-in-Alderney

Steinberg, P., \& McDowell, S. (2003). Mutiny on the bandwidth: the semiotics of statehood in the internet domain name registries of Pitcairn island and Niue. New Media and Society, 5(1), pp. 47-67.

Tax Free Gold. (2013). Alderney gold coins. Retrieved from http://tax freegold.co.uk/2003alderney5poundsconcorde.html

Van Fossen, A. (2007). Citizenship for sale: passports of convenience from Pacific island tax havens. Commonwealth and Comparative Politics, 45(1), pp. 138-163. 
Wild, J. (2013). Alderney looks to cash in on virtual Bitcoins with Royal Mint reality. Financial Times, 30 November, p. 1. Retrieved from http://www.ft.com/cms/s/0/4903fc9a-591f-11e3-a7cb00144feabdc0.html\#axzz2m5pIVRw5

Wilsenach, A. (2002). Alderney: leading regulated electronic gambling. Gaming Law Review, 6(6), pp. 491-493. 